\title{
Risk Factors of Type 2 Diabetes among Mbororo Population of Guiwa-Yangamo Village in the East -Cameroon
}

\author{
Article by, ${ }^{1 *}$ Judith Maka, ${ }^{2}$ Félix Assah, ${ }^{3}$ Clarisse Mapa-Tassou, ${ }^{4}$ Clément Kufe, \\ ${ }^{5}$ Akenji Siri and ${ }^{6}$ Jean-Claude Mbanya \\ ${ }^{1 *}$ Health of Population in Transition Research Group District hospital of Biyem- \\ assi, Yaounde, Cameroon, ${ }^{2,3,4}$ Health of Population in Transition Research Group, ${ }^{5}$ \\ District hospital of Biyem-assi, Yaounde, ${ }^{6}$ Health of Population in Transition \\ Research Group Central Hospital of Yaounde Faculty of Medicine and Biomedical \\ Sciences, University of Yaounde \\ E-mail:1*judithmani70@hotmail.com, ${ }^{2}$ kembeassah@yahoo.com, \\ ${ }^{3}$ mapatassou@yahoo.fr, ${ }^{4}$ kufekle@yahoo.co.uk, ${ }^{5}$ siriakenji@yahoo.com, \\ jcmbanya@hopitcam.net
}

\section{Introduction}

In the world in 2013, Diabetes affected 382 million of people, and 316 million were at risk of developing it. Diabetes was responsible for the dead of 5 million persons aged 20-79, that was $8,4 \%$ of the world's mortality for this age range (1). Type 2 diabetes is the most common type and is the challenge of the 21st century for health (2). Its risk factors like obesity and complications like limbs amputations and others cost much (3). It therefore presents a severe health problem for the population with low socio-economic level and disfavored groups. Described by the WHO, the minority " Autochthones ", " Aborigines » or " Indigenous " people know the abnormal high of prevalence, complications, risk factors, and a high mortality compared to non autochthones of the same age group (4),(5). In 2007, the United Nation Organization launched the declaration of the right of these $5 \%$ of the world's population who experiencing many Burden (6).

In the Sub Sahara Africa, the word «Indigenous » is contested (7),(8) and the scarcity of data on diabetes in this « indigenous « community makes the situation of diabetics complex in the " massai » of Kenya, « pygmies » and Mbororo » of Cameroon, and «San » of South Africa; these could compromise the effectiveness of the health services (9) and the stable development(10).

In Cameroon, the prevalence of diabetes moved from 1, 5\% in 1990, to 6.6\% in 2003. $80 \%$ of patients are still undiagnosed (11). Diabetes is one of the first causes of the mortality amongst patients on hemodialysis (12). As pastoralist, the Mbororo minority group is not well censored (13); they live a " complex " social relationship hence always considered as " strangers » (14). Most of the Mbororo of the East region has lost their « cheptel » due to conflicts, epidemics, climatic changes, and soil degradation. They progressively practice agriculture on borrowed soil (15). Health care is frequently inaccessible. Women, children and the old are suffering in their Camps; they could therefore develop type 2 diabetes. With our actual knowledge, no study has been carried out to determine the prevalence and the magnitude of diabetes among Mbororos. It is then necessary to investigate on their needs and risk of developing diabetes and Blood pressure like others " indigenous » populations in the world.

As to respond to this need, a project was initiated to ameliorate the access to diabetic health care in 5 villages of the Adamaoua and East region, in order to propose strategic health management of " indigenous ». As part of this project, we conducted a study based on the prevalence and risk factors of the type 2 diabetes amongst adults Mbororo in the Guiwa Yangamo village.

To present this experience, we will explore the generalities on topic, followed by the method used and results, at the end, conclusion, recommendations and some perspectives. 
Texila International Journal of Public Health

Volume 4, Issue 4, Dec 2016

\section{Method}

This study is a part of a big research project on « Amelioration of the access to diabetic healthcare in five villages in the East and adamaoua regions ". Entirely financed by the International Federation of Diabetes (IFD), this was conducted in Five villages: GuiwaYangamo, Mandjou II, Sabga, Gom-mana, Madzidou.

\section{Description of site}

Cameroon is a country in the central Africa and its population in 2011 was estimated to 19406100 inhabitants according to the National institute of statistics. It is made of 10 Regions, 58 Divisions, 360 sub-Divisions. Guiwa-Yangamo is situated in the East region, in Ngoura sub-Division. It is situated $80 \mathrm{Km}$ from the town of Bertoua on the national road, going to the Adamaoua region. It belongs to the Bétaré- Oya Health District and in the Tongo-Gandima health area. According to the authorities of the Bétaré-oya Health District, this village had about 2325 inhabitants in 2013, giving an estimated 1000 adults.

\section{Study design}

The complex sampling frame permits us to calculate the quota of participation of each village to the big research project. Our study population was adults aged 20 and above, living in Guiwa-Yangamo village.

During a week in January 2013, we interviewed 682 adults of which were 261 Mbororo, using the standard data collecting tool STEPS of WHO for surveillance and collection on non transmissible diseases. This cross-sectional study had as analysis unit, an adult Mbororo aged 20 and above, having being censored and living in Guiwa -Yangamo village for at least one year.

\section{Description of the method used and data collection}

A manual of investigators made available. These investigators were trained on the data collection. During the visit to each household, the consent of the participant was fist obtained before his/her information was collected. Data collecting tool was based on "STEPswise » approach, which permitted to obtain sociodemographic (Step1), anthropometric (Step 2), et biomedical (Step 3) information. Many variables were therefore taken into consideration : Age, matrimonial status, sex, family history of diabetes, tobacco consumption, alcohol consumption, frequency of fruits or vegetable consumption, excessive consumption of sugar, level of physical activity, high blood Pressure, weight, Height, Body Mass Index, Waist circumference, Hip circumference, (independent variables). The outcome of type 2 diabetes (dependant variable). Diabetes diagnosis is performed through a capillary Fasting Blood Sugar (FBS), using HemocueB-201RT glucometer. Normal Fasting Blood Sugar $<1.10 \mathrm{~g} / \mathrm{l}$ $(6,1 \mathrm{mmol} / \mathrm{l})$. All the participants presenting with FBS between $100 \mathrm{mg} / \mathrm{dl}$ et $125 \mathrm{mg} / \mathrm{dl}$ $(6.1 \mathrm{mmol} / \mathrm{l}$ to $6.9 \mathrm{mmol} / \mathrm{l})$, we carried out provoked hyperglycemia test in order to classify them as pre-diabetic or diabetic.

\section{Pilot study}

A pilot study was carried out on a random sample of 5 households out of the study site in a neighboring village (Mandjou I).

\section{Statistical methods used}

Data collected were registered in software called Epi Data version 3.1.

Using a descriptive analysis, we calculated the mean, Standard deviation for continuous data and the proportion for categorized data.

The analysis of quantitative data was done with the help of software STATA 11.2. The bivaried analysis to show the existing association between each different risk factor and the development of diabetes: Chi 2 test. A logistic regression was done to estimate the risk of developing diabetes. 
All the statistical analysis were adjusted to take into consideration the complex sampling and the existence of the clusters in the households when using

STATA / IC version 11.2. The Odds ratio obtained by the logistic regression was used to estimate the risk. The degree of significance of the p-value was 0,05 .

\section{Ethical Considerations}

An ethical clearance was obtained from the National Ethical Committee of Cameroon, An administrative authorization from the ministry of public health. An authorization from the administrative authorities of the study area was obtained before the data collection.

Participants had to confirm their consent before the interview and received a feedback of the study. We kept all these information's in an area not accessible by anyone who was not part of the study team. Patients were referred to a health facility in the area for a better healthcare management.

\section{Results}

The presentation of our results was done with tables and figures. We recruited a total of 682 adults in Guiwa-Yangamo including 261 Mbororo (38.1\%). Among the Adults Mbororo, 108 (41.4\%) were males and 153 (58.6\%) females. The majority of Mbororos (96.9\%) needed an interpreter during the interview and 31.1\% could express themselves in French.

Table 1: Socio-demographic characteristics of the participants

\begin{tabular}{|l|l|l|l|}
\hline Variable & Males, N (\%) & Females, N (\%) & Total, N (\%) \\
\hline Age range & & & \\
\hline $20-29$ & $24(2.2)$ & $58(37.9)$ & $82(31.4)$ \\
\hline $30-39$ & $30(27.8)$ & $48(31.4)$ & $78(29.9)$ \\
\hline $40-49$ & $19(17.6)$ & $24(17.7)$ & $46(17.6)$ \\
\hline $50-59$ & $25(23.2)$ & $13(8.5)$ & $38(14.6)$ \\
\hline $60+$ & $9(8.3)$ & $6(3.9)$ & $15(5.8)$ \\
\hline Matrimonial status & & & \\
\hline Married(e) & $84(38.4)$ & $135(61.6)$ & $219(85.2)$ \\
\hline Single & $16(88.9)$ & $2(11.1)$ & $18(7.0)$ \\
\hline Divorced(e) & $1(20.0)$ & $4(80.0)$ & $5(1.9)$ \\
\hline widower (widow) & $3(25,0)$ & $9(75.0)$ & $12(4.7)$ \\
\hline others & $0(0.0)$ & $3(100)$ & $3(1.7)$ \\
\hline Profession & & & \\
\hline Pastoralist & $16(100)$ & $0(0.0)$ & $16(6.2)$ \\
\hline Seller & $20(76.9)$ & $6(23.1)$ & $26(10.0)$ \\
\hline Farmer & $30(78.9)$ & $8(21.1)$ & $38(14.6)$ \\
\hline Housewife/pastoralist & $4(80.0)$ & $1(20.0)$ & $5(1.9)$ \\
\hline Miners & $3(100)$ & $0(0.0)$ & $3(1.2)$ \\
\hline Builder & $4(100)$ & $0(0.0)$ & $4(1.5)$ \\
\hline Tailor /Seamstress & $5(71.4)$ & $2(28.6)$ & $7(2.7)$ \\
\hline Technician/ Moto or taxi driver & $8(100)$ & $0(0.0)$ & $8(3.1)$ \\
\hline Traditional Doctor/Native Doctor & $3(100)$ & $0(0.0)$ & $3(1.2)$ \\
\hline Teacher (e) & $1(100)$ & $0(0.0)$ & $1(0.4)$ \\
\hline No profession & $6(50.0)$ & $6(50.0)$ & $12(4.6)$ \\
\hline Not available & $2(28.6)$ & $5(71.4)$ & $7(2.7)$ \\
\hline Housewife & $0(0.0)$ & $127(100)$ & $127(48.8)$ \\
\hline Pupils/student & $2(100)$ & $0(0.0)$ & $2(0.8)$ \\
\hline Coranic Teacher & $1(100)$ & $0(0.0)$ & $1(0.4)$ \\
\hline Level of Education & & & $203(78.7)$ \\
\hline Never & $74(36.5)$ & $129(63.5)$ & \\
\hline & & & \\
\hline & & & \\
\hline
\end{tabular}


Texila International Journal of Public Health

Volume 4, Issue 4, Dec 2016

\begin{tabular}{|l|l|l|l|}
\hline Less than primary & $13(48,2)$ & $14(51.8)$ & $27(10.5)$ \\
\hline Primary & $5(41.7)$ & $7(58.3)$ & $12(4.7)$ \\
\hline Secondary (form1 - 4)) & $5(100)$ & $0(0.0)$ & $5(1.9)$ \\
\hline Secondary (form 5 - upper Sixth) & $0(0.0)$ & $0(0.0)$ & $0(0.0)$ \\
\hline University & $0(0.0)$ & $0(0.0)$ & $0(0.0)$ \\
\hline Doctorate & $0(0.0)$ & $0(0.0)$ & $0(0.0)$ \\
\hline Coranic school & $8(72.7)$ & $3(27.3)$ & $11(4.3)$ \\
\hline Region of origin & & & \\
\hline Centre & $0(0.0)$ & $1(100)$ & $1(0.4)$ \\
\hline South & $0(0.0)$ & $0(0.0)$ & $0(0.0)$ \\
\hline East & $52(40.0)$ & $78(60.0)$ & $130(49.8)$ \\
\hline Littoral & $0(0.0)$ & $0(0.0)$ & $0(0.0)$ \\
\hline South West & $0(0.0)$ & $0(0.0)$ & $0(0.0)$ \\
\hline North West & $0(0.0)$ & $0(0.0)$ & $0(0.0)$ \\
\hline West & $0(0.0)$ & $0(0.0)$ & $0(0.0)$ \\
\hline Adamaoua & $42(47.2)$ & $47(52.8)$ & $89(34.1)$ \\
\hline North & $0(0.0)$ & $1(100)$ & $1(0.4)$ \\
\hline Far North & $1(100)$ & $0(0.0)$ & $1(0.4)$ \\
\hline Strangers & $13(39.3)$ & $26(60.7)$ & $39(14.9)$ \\
\hline
\end{tabular}

The majority of the participants have never been to school (78.7\%). More males (72.73\%) than females (27.27\%) have visited the Muslim Coranic School (figure 1.

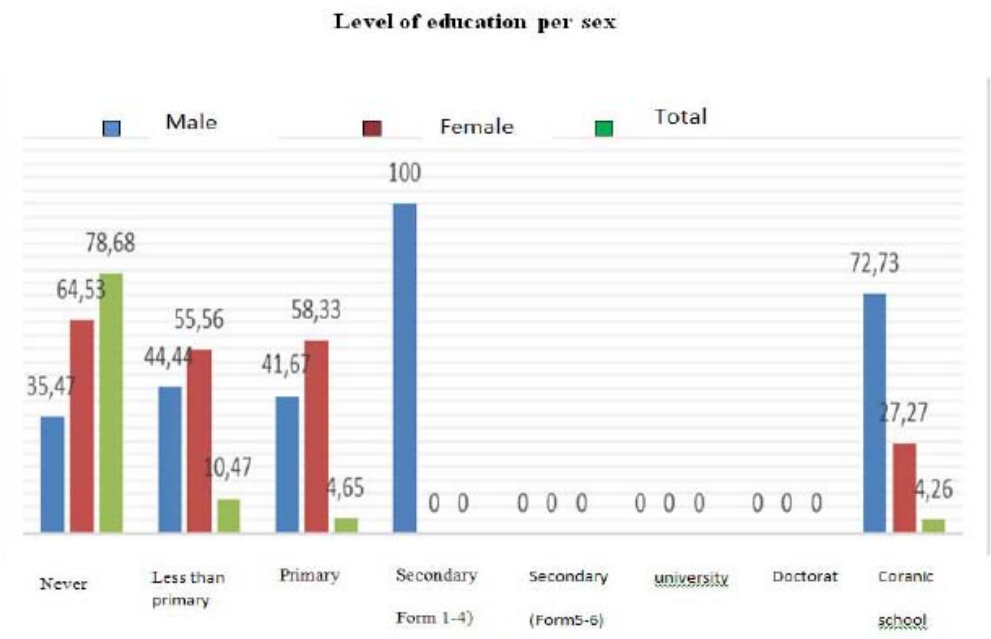

Figure1: Representation of participants according to their educational level and per sex.

More than $95 \%$ of participants have a Body Mass Index (BMI) less than $25 \mathrm{~kg} / \mathrm{m}^{2}$ with almost $50 \%$ of underweight $(\mathrm{BMI}<18 \mathrm{~kg} / \mathrm{m} 2)$. Overweight was noticed more in women $(62.50 \%)$ than in men $(37.50 \%) .91 .67 \%$ of women were obesed (waist circumference $\geq$ $88 \mathrm{~cm}$ ), against $8.33 \%$ of males (waist circumference $\geq 102 \mathrm{~cm}$ ).

In general, we noticed that vegetable consumption was reduced with advancing age; $31.50 \%$ in the age group of $20-29$ years against $5.91 \%$ in the age of 60 and above (figure 2 ). 


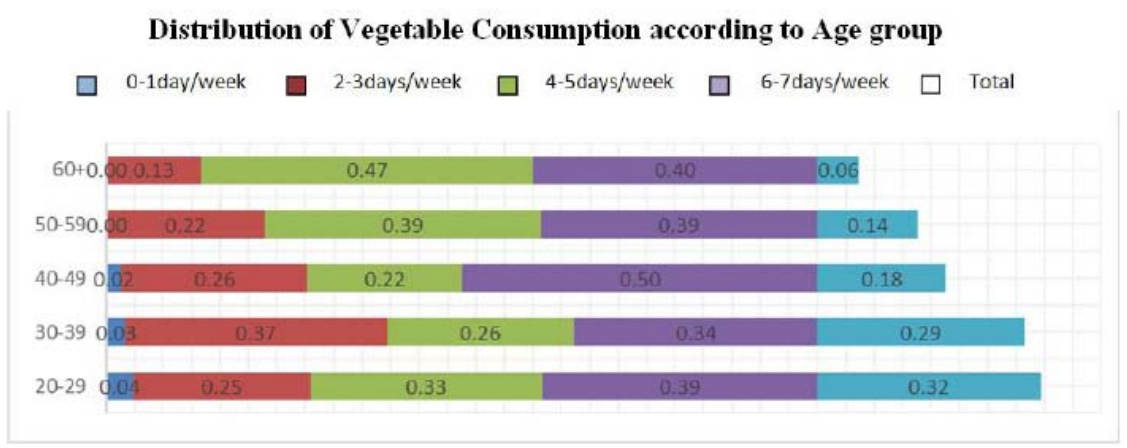

Figure 2: Representation of vegetable consumption according to age.

The prevalence of diabetes was de 2.3\%, 3.7\% in men and 1.3\% in women (figure 3).

The prevalence of impaired fasting Blood sugar in this population was $21.7 \%, 19.8 \%$ in men and 22.9\% in women (figure 4).

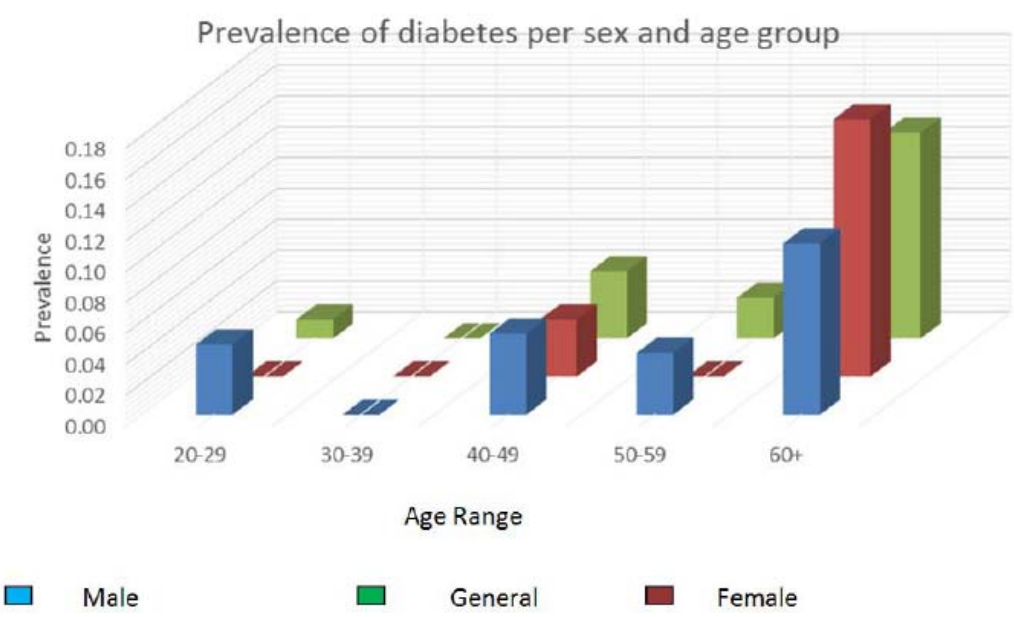

Figure 3: Prevalence of Diabetes per age group

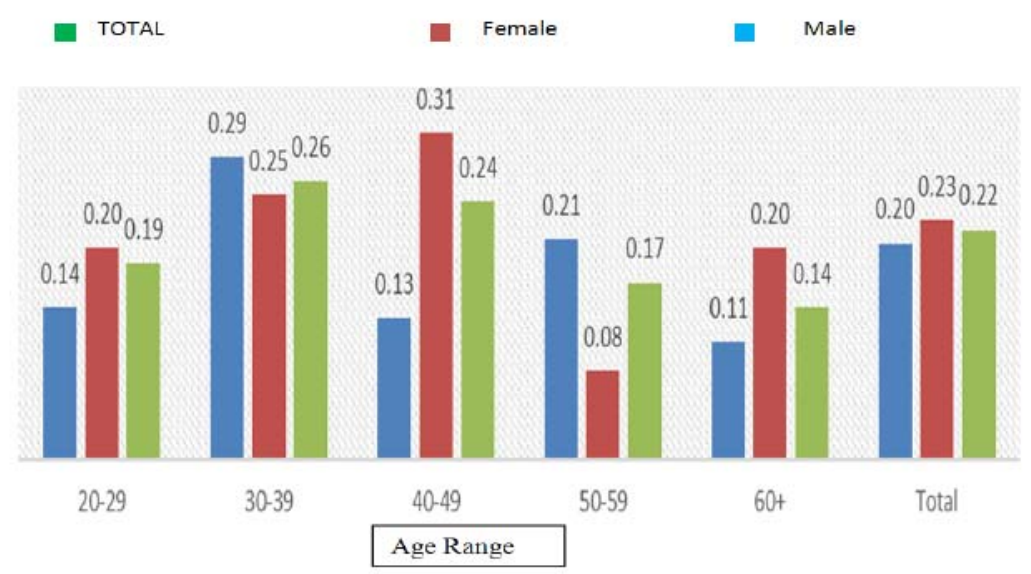

Figure 4: Prevalence of Impaired Fasting Blood Sugar (6,1mmol/l $\geq$ Fasting Blood Sugar $\leq$ $6,9 \mathrm{mmol} / \mathrm{l})$.

Amongst the 6 diabetic cases, 50\% were known diabetic and more than half were on ant diabetic treatment. The Chi 2 test permitted us to describe our diabetic population as follows:

$66.7 \%$ diabetic cases were male and $33.3 \%$ female,

83.3\% amongst them were aged 40 and above, 
Texila International Journal of Public Health

Volume 4, Issue 4, Dec 2016

All the diabetic cases had never been to school,

$50 \%$ were hypertensive,

4 diabetic cases out of the 6 added Sugar to their daily drinks.

\section{Inferential analysis}

A logistic regression was done on each independent variable. The following table summarizes the risk factors and their association with the development of type 2 diabetes in our study population.

Table 2: Risk Factors of Type 2 diabetes amongst Mbororo aged 20 and above

\begin{tabular}{|c|c|c|c|}
\hline \multirow[t]{2}{*}{ Variables } & \multicolumn{3}{|c|}{ Logistic Regression } \\
\hline & OR & CI : $95 \%$ & p-value \\
\hline \multicolumn{4}{|l|}{ Demographics } \\
\hline \multicolumn{4}{|l|}{$\operatorname{Sex}(n=260)$} \\
\hline Male & Ref & & \\
\hline Female & 0.34 & $0.07-1.73$ & 0.152 \\
\hline \multicolumn{4}{|l|}{ Age-Range (n=180) } \\
\hline $20-29$ & Ref & & \\
\hline $30-39$ & 3.64 & $0.320-41.24$ & 0.297 \\
\hline $40-49$ & 2.16 & $0.131-35.52$ & 0.589 \\
\hline $50-59$ & 12.31 & $1.04-145.64$ & 0.046 \\
\hline $60+$ & -- & & \\
\hline \multicolumn{4}{|l|}{$\begin{array}{l}\text { Matrimonial Status } \\
(n=256)\end{array}$} \\
\hline Married & Ref & & \\
\hline Single & 3.14 & $0.18-53.59$ & 0.324 \\
\hline Others & 2.81 & $0.57-13.83$ & 0.145 \\
\hline \multicolumn{4}{|l|}{ BMI $(n=254)$} \\
\hline Underweight & Ref & & \\
\hline Normal & 0.9 & $0.90-0.91$ & $<0.001$ \\
\hline Overweight & 6.61 & $6.61-6.62$ & $<0.001$ \\
\hline \multicolumn{4}{|l|}{$\begin{array}{l}\text { Waist/Hip circumference } \\
(\mathrm{n}=\mathbf{2 6 0})\end{array}$} \\
\hline$<0.90$ or $<0.85$ & Ref & & \\
\hline${ }^{>} 0.90$ or ${ }^{>} 0.85$ & 0.64 & $0.07-5.74$ & 0.608 \\
\hline \multicolumn{4}{|l|}{$\begin{array}{l}\begin{array}{l}\text { Waist Circumference } \\
(\mathbf{n}=246)\end{array} \\
\end{array}$} \\
\hline$\leq 94$ or $\leq 80 \mathrm{~cm}$ & Ref & & \\
\hline $94^{>} \&<102$ or $80^{>} \&<88 \mathrm{~cm}$ & 2.61 & $0.08-76.05$ & 0.473 \\
\hline$\geq 102$ or $\geq 88 \mathrm{~cm}$ & 4.75 & $0.07-296.48$ & 0.354 \\
\hline \multicolumn{4}{|l|}{ HTA $(n=257)$} \\
\hline Normal & Ref & & \\
\hline Pre- hypertension & 5.84 & $0.57-59.49$ & 0.094 \\
\hline Hypertension & 10.13 & $1.01-96.11$ & 0.047 \\
\hline \multicolumn{4}{|l|}{$\begin{array}{l}\text { Tobacco consumption } \\
(\mathbf{n}=\mathbf{2 5 1})\end{array}$} \\
\hline Never & Ref & & \\
\hline Ex smokers & 5.84 & $0.36-93.94$ & 0.136 \\
\hline \multicolumn{4}{|l|}{$\begin{array}{l}\text { Physical activity at work } \\
(\mathrm{n}=214)\end{array}$} \\
\hline None & Ref & & \\
\hline
\end{tabular}




\begin{tabular}{|l|l|l|l|}
\hline Little & 1.86 & $1.58-2.19$ & 0.004 \\
\hline middle & 0.81 & $0.64-1.02$ & 0.059 \\
\hline $\begin{array}{l}\text { Fruits consumption } \\
\text { (n=150) }\end{array}$ & & & \\
\hline 0day/week & Ref & & \\
\hline 1-2days /week & 0.26 & $0.14-0.49$ & 0.011 \\
\hline $\begin{array}{l}\text { Vegetable consumption } \\
\text { (n=177) }\end{array}$ & & & \\
\hline 0-1day/week & Ref & & \\
\hline 4-5days/week & 1.31 & $1.00-1.71$ & 0.049 \\
\hline $\begin{array}{l}\text { Addition sugar in } \\
\text { tea/coffee (n=257) }\end{array}$ & & & \\
\hline No & Ref & & 0.003 \\
\hline Yes & 2.71 & $2.11-3.49$ & \\
\hline
\end{tabular}

All participants aged between 50 - 59 years were 12.31 times (OR : 12.31, 95\% CI : 1.04 $145.64: \mathrm{P}=0.046)$. More at risk of developing diabetes than those with age between $20-29$ years. Participants who had high blood pressure were ten times more at risk than those who had abnormal blood pressure (OR : 10.13, 95\% CI : 1.06 - 96.11, $\mathrm{p}=0.047$ ).

Persons with overweight were 6 times more at risk of developing diabetes than those who were underweight (OR: 6.61: 95\% CI: $6.61-6.62 \mathrm{p}<0.0001)$. Those who added Sugar into their daily drinks (Coffee, Tea etc) were 2 times (OR: 2.71: 95\% CI: $2.11-3.49$; $\mathrm{p}=0.003$ ) more at risk of developing diabetes with respect to those who did not add. Those who consumed vegetables 4 to 5 days per week were one time (OR: 1.31; CI: $1.00-1.71, \mathrm{p}=0$. 049) at risk of developing diabetes compared to those who did not at all. All participants practicing physical activities during the day were one time at risk (OR: 1.86; CI: $1.58-2.19$, $\mathrm{p}=0.004)$.

Discussion: This study carried out in a rural area in the East region of Cameroon had as principal objective to determine the prevalence and to describe the risk factors associated with the development of type 2 Diabetes in the adult "' Indigenous " Mbororo population in the Guiwa- Yangamo village. The result showed that diabetes is present in this indigenous population of Cameroun. Its prevalence is 2, 3\% and the impaired glucose tolerance is 21 . $7 \%$. Risk factors like age, high blood pressure, excess sugar in their diet, little physical activity were associated to the development of diabetes in this population.

This prevalence is smaller compared to that obtained in other rural zones in Cameroon probably due to the fact that they are physically more active than in urban zones and most of them have an underweight. This prevalence is relatively identical to the value of 2,6\% found amongst the Touareg rarers of Mali (9). But the distributions is contrary to that which was described in the Touaregs of Mali where fat women were less active than men and had a much more prevalence of diabetes $35 \%$ than $4.2 \%$ in men (9). This is probably linked to the progressive modification of the lifestyle of the Mbororos. This low prevalence which respect to the $12 \%$ reported amongst the "Aborigines'” of Australia (16) makes us to think that there would be a specific protecting factor amongst the Mbororos of Cameroun. Could this not be attributed to their underweight?

Amongst the Mbororos of the East, the prevalence of the impaired Fasting Blood sugar, 54 on 249 (21.7\%), that is $19.8 \%$ in men and $22.9 \%$ in women. This tendency can be explained also that in their Community, the” autochthone” Mbororo have just changed their lifestyle. As concerns pre- diabetes, we noticed that female Mbororos shall, in the nearest future (4 to 5 years) be at a higher risk of developing diabetes if nothing being done. Men are physically more active benefiting from a protector effect than women. This calls for a special attention in this group of population to prevent them from becoming diabetic.

The $50 \%$ of the diabetic cases were not informed of their pathology at the moment of diagnostic, hence the need for the IFD to insist on screening in order to identify patients who 
are not aware of their situation. This value is low compared to that described in the CAMBOD survey in 2008 where about $80 \%$ were not aware of their pathology(11). Is it due to the effect of sensitization or to the reduced sample size of our study?

After reviewing all the analysis we came out with the following risk factors attributed to the development of type 2 diabetes amongst the adult Mbororo in the Guiwa- Yangamo village. In our study population the most representative age group was between 20 and 39 Years and that of the diabetic cases from 40 years. This result is similar to those found in the CAMBOD survey in 2008 (11) which was on a more varied and larger population in Cameroon. This population is made up of mostly youths and the diabetic complications shall be more serious due to the high cost it shall generate. Advanced age especially in the between 50 - 59 years was statistically associated to the outcome of diabetes in the Mbororos. This has been described in a rural population in Bangladesh where the advanced age was attributed to the development of diabetes (17). With the advanced age, we noticed a reduction of physical activity and a probable development of obesity.

In the Mbororo population, overweight had a strong association with the development of diabetes in adults. BMI is therefore the best predicator of obesity (16), contrary to an autochthones population in Ireland with more than 90\% abdominal obesity (18). This result in "Mbororos" is different from which was described in an urban Cameroonian population where obesity was more associated to the development of diabetes (19). Could there be specificity amongst the Mbororos with respect to the rest of the Cameroonians?

Most of the Mbororo were married and kept the family culture. In general, in this zone, local tea or "thaî "is being consumed throughout the day and is being served within the family with a lot of sugar. This consumption or the fact that sugar is being added in the tea showed the level of ignorance of the population and their exposure to diabetes. Future studies shall be necessary to evaluate the perception of this disease and/or sugar in this community. Addition of sugar has been shown to be a risk factor associated to the development of diabetes in Cameroon(19). It has been demonstrated in literature that excess of sugar exposes one to the development of diabetes. This family life is a point showing the responsibility of the man and could be used positively when putting in place education strategies for households in general.

Amongst the Mbororo, 50\% of the diabetic cases had high blood pressure. This prevalence was higher compared to that obtained in European diabetics (17) and African diabetes (19). This value was two times higher than that described among the Touaregs diabetics of Mali (20.44\%). This demonstrated that Mbororos in the nearest future, are exposed to cardiovascular complications linked to this co morbidity (diabetes and high blood pressure) if nothing is done. This could be linked to the excess consumption of salt in vegetables, and to the quality of life style (e.g stress) that this population is experiencing. Low physical activity was associated to the development of diabetes. Amongst the risk factors described in the $6^{\text {th }}$ edition of the IFD Atlas. This factor is described as being associated to the obesity (1). It was noticed amongst the Touaregs of Mali as the first factor responsible in women as compared to men. The African culture obliges the man to be more active physically and the woman to stay backs at home to take care of family. Also fat women were more appreciated (9). This is seen amongst the Mbororos where women are less active than men. This partly explains why women have a higher risk to develop diabetes in the future than men. The Mbororos have as primary activity farming contrary to what we thought of because the community is one known to be made up of cattle rarers. Today they are obliged due to certain circumstances (20) to carry out activities like others.

More than $50 \%$ of our participants oral even those who were diabetic were from the East. This study site did not favor the movements because it was still enclave some year back. This could explain their greater representatives followed by that of Adamaoua which is a region closer to them.

In this forest zone, vegetables are the main source of nutrition. The consumption of vegetables was higher in the age between 40-49 years; its age of maturity, man is more active and can afford for pleasure. These vegetables are being prepared in different ways and could 
be consumed with much salt and oil. This could explain the association between the consumption of vegetables more than 4 to 5 days with the development of diabetes. Excess consumption of salt could lead to high blood pressure and excess consumption of fatty foods to obesity. All these two factors could favor the development of diabetes.

\section{Advantage of the study}

A censor carried out on the adult population enabled us to have an idea of the population in order to put in place a good data collection strategy. It enabled us to extract Mbororos who were 20 years and above and those who were diabetic as our observations showed to be our participants in survey.

The WHO "STEPS wise" questionnaires with different sections helped us for data collection. It was pretested before using to answer comprehension and feasibility.

Face to face interview was beneficial for translation to the participant, avoided discrimination, ensured minimum confidentiality and above all facilitated meeting with the female participant who were mostly housewives.

The investigators were trained on how to use the tool are they carried out a role play to better understand the tool.

Some specificities of Epi info Software were used to eliminate variables which did not respect the norms to ensure quality and control.

The analysis of our data was done using STATA 11.2 software taking into consideration the complexity of the sampling, the existence of clusters are uncompleted data bases.

The preferential choice of the Glucometer Hemocue B20IRT which gives the best result of blood sugar at an ambient temperature.

\section{Limitation of the study}

It's a transversal study; therefore, it describes the situation of the population only at a given moment. Also it is difficult to generalize this survey without carrying out a more detailed and analytic study and also on a larger sample size. This survey carried out on a psychologically vulnerable population was susceptible to selection and/or information's biases. This population is less exposed or opened out due to their very reserved attitude hence making data collection at times difficult.

\section{Conclusion}

The central objective of this study was attained following the epidemiological profile description of the adult Mbororo of Guiwa -Yangano and the results showed that the sample population studied had a very little knowledge on diabetes. They had a very little or no access to health care and medications. The prevalence of type 2 diabetes in adult Mbororo age 20 and above in Guiwa- Yangamo is $2.3 \%$ and almost 22\% have the risk of developing diabetes if nothing is done. This situation needs the re- enforcement of public health actions in this reserved community but rich in gracing culture. The following three axes seem to be priority: prevention screening and adapted health care provision.

\section{Competing interests}

The authors declared they had no competing interest. The authors declared they benefited from the funds of the IFD.

\section{Author's contributions}

Judith Maka: Conception, design, data collection, data analysis, and drafted the manuscript, Klement Kufe : Conception, design, data analysis and reviewed the manuscript, Félix Assah: Reviewed the manuscript, Akenji Siri: Translated the manuscript, Clarice Mapa Tassou: Reviewed the manuscript, Jean-Claude Mbanya: Conception, design, supervision and reviewed the manuscript. 
Texila International Journal of Public Health

Volume 4, Issue 4, Dec 2016

\section{Acknowledgements}

We thank the participants for taking part in this survey, thereby helping to make advocacy and making health policies backed by local evidence. We also thank the IFD, all the research team members, the staff of the Catholic University of the Central Africa who somehow contributed to the success of this work.

\section{References}

[1.] Aguiree F, Brown A, Cho NH, Dahlquist G, Dodd S, Dunning T, et al. IDF Diabetes Atlas $\square$ : sixth edition [Internet]. International Diabetes Federation; 2013 [cited 2016 Oct 26]. Available from: http://dro.deakin.edu.au/view/DU:30060687

[2.] American Diabetes Association. Diagnosis and Classification of Diabetes Mellitus. Diabetes Care. 2010 Jan 1;33(Supplement 1):S62-9.

[3.] Almutairi N, Alkharfy KM. Direct medical cost and glycemic control in type 2 diabetic Saudi patients. Appl Health Econ Health Policy. 2013 Dec;11(6):671-5.

[4.] Boutrais J. Les savoirs pastoraux des Mbororo de l'Adamaoua $\square$ : évolution et rapports au développemment. In: Holtedahl L, Gerrard S, Njeuma MZ, Boutrais J, Le Rôle du Savoir dans le Développement Régional $\square$ : Conférence Internationale, Tromso (NOR), 1993/09/19-21, editors. Le pouvoir du savoir $\square$ : de l'Arctique aux Tropiques = The power of knowledge: from the Arctic to the Tropics [Internet]. Paris: Karthala; 1999 [cited 2016 Oct 26]. p. 146-66. (Hommes et Sociétés). Available from: http://www.documentation.ird.fr/hor/fdi:010017690

[5.] Brimblecombe J, Mackerras D, Garnggulkpuy J, Maypilama E, Bundhala L, Dhurrkay R, et al. Leanness and type 2 diabetes in a population of indigenous Australians. Diabetes Res Clin Pract. 2006 Apr;72(1):93-9.

[6.] Bhowmik B, Afsana F, My Diep L, Binte Munir S, Wright E, Mahmood S, et al. Increasing prevalence of type 2 diabetes in a rural bangladeshi population: a population based study for 10 years. Diabetes Metab J. 2013 Feb;37(1):46-53.

[7.] Fouda H, Muna W, Ashutangtang, al. Mortalité chez les Hemodialysés chroniques au Cameroun. University of Yaounde I; 2006.

[8.] Hadley L, Kooijmans M. Pour lee diabete et le developpement. point de Vue 4 nouvelles En Bref 61A. cAmpAgne mondiAle. 58th ed. 2013;8.

[9.] Health of Population in Transition (HoPiT) Research Group. Cameroon Burden of Diabetes (CAMBoD) Baseline survey Report. Yaoundé; 2004.

[10.] International Diabetes Federation, World Diabetes Foundation. Expert Meeting on Indigenous people, Diabetes and development. Copenhagen; 2012 March.

[11.] Jago C. American Diabetes Association - 66th scientific Sessions. Washington DC, USA; 2006.

[12.] Kufe CN, Klipstein-Grobusch K, Leopold F, Assah F, Ngufor G, Mbeh G, et al. Risk factors of impaired fasting glucose and type 2 diabetes in Yaoundé, Cameroon: a cross sectional study. BMC Public Health. 2015 Jan 31;15:59.

[13.] Ministère des Affaires sociales. Annuaire statistique du Cameroun de juin 2012. Yaounde Cameroun; 2012.

[14.] Nakashima D., Galloway Mclean K, Thulstrup H., Ramos Castillo A, Rubis J. Weathering Uncertainty: Traditional knowledge for climate change assessment and adaptation. UN University and UNESCO; 2012.

[15.] Nicolaisen I. Les populations indigènes atteintes de diabète: négligées ou en danger. diabetes voice. 51st ed. 2006;34-6.

[16.] Ohenjo N 'ori, Willis R, Jackson D, Nettleton C, Good K, Mugarura B. Health of Indigenous people in Africa. Lancet Lond Engl. 2006 Jun 10;367(9526):1937-46.

[17.] Pelican M. Mbororo on the move: from pastoral mobility to international travel. J Contemp Afr Stud. 2011 Oct 1;29(4):427-40.

[18.] Pink B, Allbon P. The health and welfare of Australia's Aboriginal and Torres Atrait Islander peoples. Commonwealth of Australia. 2008; 
[19.] Scott J, Gavin J, Egan AM, Avalos G, Dennedy MC, Bell M, et al. The prevalence of diabetes, pre-diabetes and the metabolic syndrome in an Irish regional homeless population. QJM Mon J Assoc Physicians. 2013 Jun;106(6):547-53.

[20.] World Health Organization. Health of indigenous peoples. 2007. 